\title{
DIFFERENT SENSITIVITY TO ISOPRENALIN IN MICE OF TWO STRAINS AND ITS CHANGES WITH AGE
}

\author{
M. DOSTÁL, A. GAJA, M. HLUBINKA, D. ŽERNÍČEK and M. POSPIŠIL ${ }^{1}$
}

Department of Pathological Physiology, Faculty of Medicine, Masaryk University, 66243 Brno, Institute of Biophysics, the Czechoslovak Academy of Sciences, 135 Královopolská, 61265 Brno

Received fune 25, 1990

\begin{abstract}
M. Dostál, Gaja A., M. Hlubinka, D. Žerníček and M. Pospíšil: Different Sensitivity to Isoprenalin in Mice of Two Strains and Its Changes with Age. Acta vet. Brno, 60, 1991: 225-230.

Parameters of locomotor activity of mice of two strains (conventional male [CBA $\times$ C57BL] $10 F_{1}$ mice and Conventional random breed male ICR mice) are reported together with their per cent mortality after administration of isoprenalin (ISO) at $400 \mathrm{mg} \cdot \mathrm{kg}^{-1}, 700 \mathrm{mg} \cdot \mathrm{kg}^{-1}$ and $750 \mathrm{mg} / \mathrm{kg}$ body mass in mice aged 3 months and at $400 \mathrm{mg} \cdot \mathrm{kg}^{-1}$ body mass in animals aged 5 months. Age-dependent changes in body mass and myocardial mass were assessed. It is concluded that mice of the two strains differed in their sensitivity to ISO. The oz served higher resistance of $(\mathrm{CBA} \times \mathrm{C} 57 \mathrm{BL} / 10) \mathrm{F} 1$ mice to ISO toxicity can be related to their higher locomotor activity and lower kody mass.
\end{abstract}

Isoprenalin, mice, myocardium, staircase test

The sensitivity to isoprenalin (ISO) is conditioned by a number of factors the quality of which varies from species to species (Venault et al. 1986). Of particular importance is the cardiotoxic effect of ISO inducing myocardial lesions of coagulative myocytolysis (COAM) type with subsequent development of necroses (Milei et al. 1978) within a very short period of time. Therefore ISO is used mostfrequently in experiments designed to induce primary cardiomyopathy. In response to its application $\mathrm{Ca}^{++}$and $\mathrm{Na}^{+}$ions in the myocardium increase rapidly, the energy conditions are affected, etc. In addition to the direct effect on the myocardium the process involves the mechanism of release of free radicals and enhanced lipid peroxidation (Ohta et al. 1986).

In conventional male $(\mathrm{CBA} \times \mathrm{C} 57 \mathrm{BL} / 10) \mathrm{F}_{1}$ mice no significant biochemical or morphological myocardial changes have been found after administration of ISO in doses of 10 to $100 \mathrm{mg} . \mathrm{kg}^{-1}$ body mass which are used routinely in rats (Fleckenstein et al. 1977; Fal tová et al. 1983b). Mice of the ICR strain exhi ited in our previous experiment higher sensitivity to ISO. One of the factors underlying this different resistance of conventional male (CBA $\times$ C57BL/10) F1 mice might be their different locomotor activity. The present study was therefore designed to compare the effects of ISO on conventional male (CBA $\times$ C57BL/10) F1 mice together with their locomotor activity with the corresponding data obtained for ICR mice.

\section{Materials and Methods}

The experimental animals were 60 conventional male (CBA $\times$ C57BL/10) F1 mice (breeding colony of Institute of Biophysics, Czechoslovak Academy of Sciences, Brno) aged 3 months and having $33.3 \pm 1.8 \mathrm{~g}$ in body mass and 50 conventional random breed male ICR mice (breeding colony of VELAZ, Prague, Czechoslovakia) aged 3 months and having $37.4 \pm 3.0 \mathrm{~g}$ in body mass. One week before the experiment the mice were transferred to the laboratory and kept there 


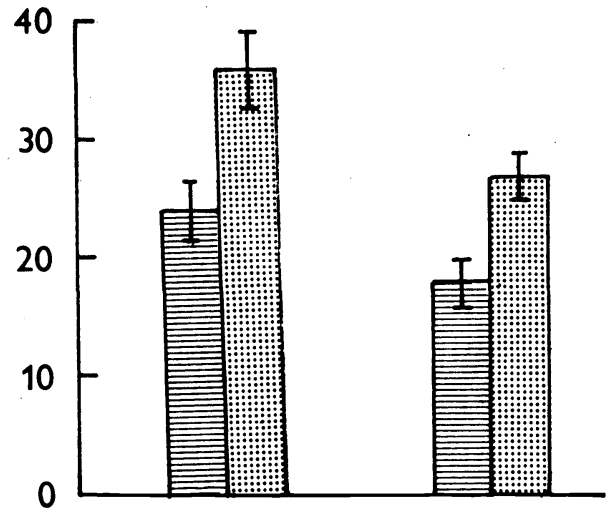

Fig. 1. Locomotor activity of mice of the two strains

- ICR mice

- (CBA $\times$ C57BL/10) F1 mice

on the vertical axis, the num ser of steps climbed is indicated

in conditions corresponding to those of the animal rooms where they had been reared. Throughout the experiment the environmental temperature was maintained at $21 \pm 1^{\circ} \mathrm{C}$ and the lighting regime corresponded roughly to the natural light-dark cycle. The atmospheric pressure fluctuations did not exceed $5 \mathrm{kPa}$, compared with the measurements made on the days preceding and following each test. All tests were carried out between 6 and $12 \mathrm{a} . \mathrm{m}$.

The locomotor activity of the mice of $t$ oth strains was tested in a PVC box with a staircase composed of 5 identical steps (Simiand et al. 1984). Each animal was placed singly on the floor of the box. The number of steps climbed and the number of rears were counted over a 3-min period. Since the test was designed originally to assess the locomotor activity of mice in an unknown environment, the tests had to be repeated until standard values were obtained (i. e. until the results of the preceding test did not differ significantly from those of the following test). Mice of the two strains were each tested alternately to reduce the environmental influences to a minimum. After each animal had been tested, the staircase was cleaned by removing wood shavings dusted all over its area in a thin layer and by replacing them with new ones to eliminate any olfactory cue.

After being tested for their locomotor activity, the the mice of the two strains were divided into groups of 8 to 12 animals and injected s. c. with ISO at the dose of $400 \mathrm{mg} . \mathrm{kg}^{-1}, 700 \mathrm{mg}$. . $\mathrm{kg}^{-1}$ and $750 \mathrm{mg} . \mathrm{kg}^{-1}$ body mass. In each group the number of deaths was recorded and the myocardia were removed (immediately after death in animals that died and within $24 \mathrm{~h}$ of ISO administration in those that survived). The myocardia were weighed immediately after removal.

Besides the foregoing groups, one experimental group (plus controls) of mice of each of the two strains were kept in the same environment, with food and water freely available, for another 2 months. These animals were then injected s. c. with ISO at $400 \mathrm{mg} \cdot \mathrm{kg}^{-1}$ body mass and their myocardia were removed and weighed as in the foregoing groups.

The locomotor activity was assessed by the t-test for non-paired values $(P<0.01)$, the body and myocardial mass of 3 - and 5 -month old mice by Student's t-test $(P<0.05)$ and the death rate by means of the modified chi-square test according to Fischer and Yates (Wardlaw 1985).

\section{Results}

Evaluation of the locomotor activity showed significant differences $(P<0.01)$ between mice of the two strains: staircase test, $36+3.5$; rearing, $27 \pm 2.5$ in $(\mathrm{CBA} \times \mathrm{C} 57 \mathrm{BL} / 10) \mathrm{F} 1$ mice versus staircase test, $24 \pm 2.5$; rearing, $18 \pm 2.0$ in ICR mice (Fig. 1). Significant differences in death rate were found between mice of the two strains in animals injected with ISO at $700 \mathrm{mg} \cdot \mathrm{kg}^{-1}$ and 750 $\mathrm{mg} \cdot \mathrm{kg}^{-1}$ body mass and in those injected with ISO at $400 \mathrm{mg} / \mathrm{kg}$ body mass two months later (Table 1 ).

Significant differences $(P<0.05)$ in body mass were found between 3-month old and 5-month old mice of both strains: $(\mathrm{CBA} \times \mathrm{C} 57 \mathrm{BL} / 10) \mathrm{F} 1$ mice, 
Table 1

Mortality of mice after administration of different isoprenalin dosed

\begin{tabular}{|c|c|c|}
\hline $\begin{array}{l}\text { Isoprenalin } \\
\left(\mathbf{m g} \cdot \mathbf{k g}^{-1}\right)\end{array}$ & $\begin{array}{l}\text { ICR mice } \\
\% \text { mortality }\end{array}$ & $\begin{array}{c}\mathrm{CBA} \times \mathbf{C} 57 \mathrm{BL} \\
\text { mice } \\
\% \text { mortality }\end{array}$ \\
\hline $\begin{array}{l}400 \\
700 \\
750 \\
400 \$\end{array}$ & $\begin{array}{c}0 \\
80+ \\
100+ \\
100+\end{array}$ & $\begin{array}{c}0 \\
12.5^{+} \\
60^{+} \\
0^{+}\end{array}$ \\
\hline
\end{tabular}

$\S-$ Administered to animals 2 months older.

+ - Statistically significant difference $(P<0.05)$

$33.3 \pm 1.8 \mathrm{~g}$ and $36.8 \pm 2.5 \mathrm{~g}$; ICR mice, $37.4 \pm 3.0 \mathrm{~g}$ and $46.3 \pm 3 \mathrm{~g}$ at 3 and 5 months of age, respectively. Significant differences $(P<0.05)$ in body mass were also found between mice of the two strains at both 3 and 5 months of age. Comparison of the myocardial mass showed no significant differences between mice of the two strains. Significant differences $(P<0.05)$ in the myocardial mass were found only between 3-month old and 5-month old animals of both strains: $(\mathrm{CBA} \times \mathrm{C} 57 \mathrm{BL} / 10) \mathrm{F} 1$ mice, $123 \pm 30.7 \mathrm{mg}$ and $172.3 \pm 20.1 \mathrm{mg}$; ICR mice, $116.3 \pm 23.2 \mathrm{mg}$ and $185.5 \pm 13.8 \mathrm{mg}$ at 3 and 5 months of age, respectively (Table 2).

Table 2

Body mass and myocardial mass of 3-month old and 5-month old mice

\begin{tabular}{|c|c|c|c|c|c|c|}
\hline \multirow[b]{2}{*}{$\begin{array}{c}\text { Age } \\
\text { (months) }\end{array}$} & \multicolumn{4}{|c|}{$\begin{array}{l}\text { Body mass } \\
(\mathrm{g})\end{array}$} & \multicolumn{2}{|c|}{$\begin{array}{c}\text { Myocardial mass } \\
(\mathrm{mg})\end{array}$} \\
\hline & $\underset{\text { mice }}{(\mathrm{CBA} \times \mathrm{C} 57 \mathrm{BL})}$ & & & ICR mice & $\begin{array}{c}(\mathrm{CBA} \times \mathrm{C} 57 \mathrm{BL}) \\
\text { mice }\end{array}$ & ICR mice \\
\hline 3 & $\overbrace{36.8}^{33.3 \pm 1.8}$ & $\leftarrow$ & $\begin{array}{l}\rightarrow \\
\rightarrow \\
\rightarrow\end{array}$ & 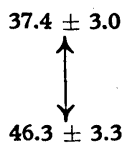 & $\underbrace{123.7 \pm 30.7}_{172.3}$ & 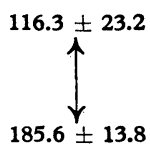 \\
\hline
\end{tabular}

$\longleftrightarrow=$ Statistically significant difference $(P<0.05)$.

\section{Discussion}

ISO induces stress reaction in the body by its beta-adrenergic effect ( Gudbjarnason et al. 1987). Of major importance is its toxicity for the myocardium, resulting in very rapid acceleration of $\mathrm{Ca}^{++}$ion penetration into myocardial cells (Milei et al. 1978), further ionic changes, and biochemical changes in lipid metabolism (Gudbjarnason et al. 1987; Papies et al. 1989). The consequences are total disruption of the metabolism of heart cells, development of dispersed necroses (Fleckenstein et al. 1977) and ventricular fibrillation (Balasz et al. 1983), with low ISO doses $\left(1 \mathrm{mg} . \mathrm{kg}^{-1}\right)$ being responsible for fibrillation (rapid effect) and higher doses (40 to $80 \mathrm{mg} . \mathrm{kg}^{-1}$ ) exerting necrotizing effects (slower course) (Gudbjarnason et al. 1987). The outcome is fatal.

The sensitivity to ISO depends on age, with young animals being more resistant (Faltová et al. 1983a; Kojima 1983; Herzig et al. 1987), sex (Faltová 
et al. 1980) and body mass (Faltová et al. 1983a; Gudbjarnason et al. 1987). An important underlying factor is the content of adipose tissue, the metabolism of which is affected by ISO: free radicals and toxic fatty acid peroxides are released (Ohta et al. 1986). This phenomenon comes into operation particularly in old and obese animals. Added to this are hereditary factors (Mráz et al. 1986) that are also associated with higher adipose tissue content in ISO-sensitive animals and higher glycogen content in the heart and liver of ISO-resistant animals. In addition to inter-strain differences (Mráz et al. 1986; Papies et al. 1989) inter-species differences have been found. Higher ISO doses are required to induce myocardial changes in chickens than in rats and rabbits (Ohta et al. 1986). Similarly, golden hamsters are more resistant to ISO than rats (Fleckenstein al. 1977).

Other influences to be mentioned are increased activity of ISO-degrading enzymes, increased liver activity and lower concentration of beta-adrenergic receptors in the myocardium. Added to this is the fact that the sensitivity to ISO is reduced by locomotor activity (Faltová et al. 1983b).

From the afore-mentioned observations it can be concluded that enhanced locomotor activity results in increased energy consumption, which may be related to a reduction in adipose tissue mass. Furthemore, the higher energy metabolism can be interpreted to indicate a higher level of beta-receptor regulating substances, which would result in a reduction of beta-receptors in the tissues and, consequently, in a lower sensitivity to exogenously administered beta-mimetics such as ISO, the toxicity of which becomes apparent only after extremely high doses. Results of our experiments demonstrating a lower sensitivity of $(\mathrm{CBA} \times \mathrm{C} 57 \mathrm{BL} / 10)$ F1 mice to ISO (as compared to ICR mice) can te related to their higher locomotor activity and lower body mass.

In our study the body mass increased with age in both strains of mice. The afore-mentioned factors can therefore be cumulated. The resistance to ISO was found to decrease with age, which is in keeping with the observations reported by other investigators for rats (Kojima et al. 1983; Faltová et al. 1983a). The finding of increased sensitivity to ISO in our 5-month old mice of ICR strain was presumably the result of both ageing and increased body mass.

An important fact is the absence of major differences in myocardial mass between individual strains of mice. The relatively higher myocardial mass of (CBAX $\times$ C57BL/10) F1 mice may be the result of their higher cardiovascular locomotor activity, a load to the cardiovascular system, which then adapts itself more readily to the cardiotoxic noxa in question. Thus $(\mathrm{CBA} \times \mathrm{C} 57 \mathrm{BL} / 10) \mathrm{F} 1 \mathrm{re}-$ ceived a relatively lower ISO dose, considering the higher mass of the target organ (myocardium). It would therefore be better to administer ISO not according to body mass but according to myocardial mass, but this is not practicable.

\section{Rozdílná senzitivita na isoprenalin u myší dvou kmenů a její ovlivnění věkem}

V práci je uvedena rozdílná senzitivita dvou myších kmenů, konvenčních samců (CBA $\times$ C57BL/10) F1 a konvenčních náhodně křížených ICR myších samcủ, na kardiotoxickou noxu - isoprenalin, aplikovaný s.c. u myší 3 měsíce starých $\mathrm{v}$ dávkách $400 \mathrm{mg} \cdot \mathrm{kg}^{-1}, 700 \mathrm{mg} \cdot \mathrm{kg}^{-1}$ a $750 \mathrm{mg} \cdot \mathrm{kg}^{-1}$ a u myší 5 měsíců starých v dávce $400 \mathrm{mg} \cdot \mathrm{kg}^{-1}$. Ve všech prípadech kromě dávky $400 \mathrm{mg} \cdot \mathrm{kg}^{-1}$ 
u 3měsíčních myši byl zjištěn rozdil $\mathrm{v}$ senzitivitě, dokumentovaný významně vyšší mortalitou myší ICR. To znamená vyšší senzitivitu u kmene ICR a u starých jedinců.

Souběžně s mortalitou po aplikaci isoprenalinu byla sledována hmotnost těla a hmotnost myokardu. Byla zjištěna významně vyšši hmotnost těla u myší ICR ( $\mathrm{p}<0.05)$. $\mathrm{V}$ hmotnosti myokardu však nebyl nalezen významný rozdíl. Tělo i myokard zvyšovaly svou hmotnost $\mathrm{v}$ závislosti na věku proporcionálně. Vyšší senzitivita myší ICR je zde dávána do souvislosti s jejich relativně nižší hmotností myokardu a nižší bazální motorickou aktiyitou, zjištovanou schodištovým testem $(\mathrm{p}<0.10)$. Vyšší rezistence $\mathrm{k}$ isoprenalinu pozorovaná $u$ myši $(\mathrm{CBA} \times \mathrm{C} 5 \mathrm{BL}$ 110) F1 může být dávána do souvislosti s jejich vyšší motorickou aktivitou a nižší tělesnou hmotností.

\section{Расхождения в чүвствительности к изопреналину у мышей}

В работе приводятся резултаты разной чүвствительности двух групп мышей - (CBA $\times \mathrm{C} 57 \mathrm{BL} / 10)$ F1 и ICR - к кардиотоксической ноксы-изопреналина, подкожно вводимой мышам в возрасте 3 месяца дозой 400 мг.кг-1, 700 мг.кг-1 и 750 мг.кг-1 и мышам в возрасте 5 месяцев дозой 400 мг.кг-1. Во всех случаях, за исключением дозы 400 мг.кг-1 мышам в возрасте 3 месяца, была выявлена разница в чүвствительности, вылившаяся в более высокой смертности мышей ICR. Это свидетельствует о более высокой чүвствительности ICR и старших особей.

Одновременно со смертностью после применения изопреналина исследовали массу тела и массу миокарда. Была установлена сүщественно более высокая масса тела у мышей ICR $(\mathrm{p}<0,05)$. В массе миокарда не была установлена сүщественная разница. Тело и миокард үвеличивали массу в зависимости от возраста весьма пропорционально. Более высокая чүвствительность мышей С приводится в данном случае во взаимосвязь с относительно более низкой массой миокарда и более низкой массой миокарда и более низкой базальной двигательной активностью, устанавливаемой лестничным тестом $(p<0,01)$.

\section{References}

BALASZ, T.-JOHNSON, G.-JOSEPH, X.-ERREICH, S.-BLOOM, S.: Sensitivity and resistance of the myocardium to the toxicity of isoproterenol in rats. Myocardial Injury, ed. J. J. Spitzer, Plenum Publ. Corp., 1983: 534-577

FÁLTOVÁ, E. - MRÁZ, M.-PROCHÁZKA, J.-SEDIVÝ, J.: The effect of pregnancy and lactation on the development of experimental heart lesion. Physiol. bohemoslov., 29, 1980: $305-312$

FALTOVÁ, E. -MRÁZ, M.-ŠEDIVÝ, J.: Protective effect of isoprenalin pretreatment on the cardiotoxicity of the same drug. Physiol. bohemoslov., 32, 1983a: 307-318

FALTOVA, E.-PAR̆IZKOVA, J.-MRÃZ, M. - SEDIVYY, J.-ŠPÁTOVÁ, M.: Influence of motor activity on the development of isoprenaline-induced heart lesion. Physiol. bohemoslov., 32, 1983b: 203-209

FLECKENSTEIN, A.-JANKE, J.-FREY, M.-HEIN, B.: Zum Mechanismus der kardioprotektiven Wirkung von Triamteren and Rattenherzen, Myokardschutz durch Steigerung der extrazellulären $\mathrm{K}^{+}$und $\mathbf{M g}^{++}$Konzentrationen. Arzneimittel. - Forsch. (Drug Res.), 27, 1977: 382-389

GUDBJARNASON, S.-BENEDIKTDÓTTIER, V. E.: Cardiac membrane lipids during 
stress - biochemical and pharmacological aspects. Cardiovascular Pharmacology, 87, ed. J. G. Papp, Akadémiai Kiadó, Budapest 1987: 429-438

HERZIG, J. W.-GERBER, W.-SALZMANN, R.: Heart failure and $\mathrm{Ca}^{++}$activation of the cardiac contractile system: hereditary cardiomyopathy in hamsters (BIO 14.6), isoprenaline overload and the effect of APP 201-533. Basic Res. Cardiol., 82, 1987: 326-340

KOJIMA, M.-SPERELAKIS, N.-JOHNSON, G.-ERREICH, S.-BALASZ, T.: Age-dependent changes in electrophysiologic characteristics of fast and slow action potential in rat papillary muscle. Can. J. Pharmacol., 61, 1983: 1509-1515

MILEI, J. - NÚNEZ, R. G.-RAPPAPORT, M.: Pathogenesis of isoproterenol-induced myocardial lesions: its relation to human coagulative myocytolysis. Cardiology, 63, 1978: 139-151

MRAZ, M. -FALTOVA, E.-LINCOVA, D. - SEDIVY, J. - GAIER, N. - MUHLBACHOVA, E. - CERNOHORSKÝ, M. - VRANA, A.: Genetic differences in the resistance of rats to isoprenalin-induced heart lesions. Basic Res. Cardiol., 81, 1986: 74-82

OHTA, H. - AZUMA, J. - ONISHI, S. - AWATA, N. - TAKIHARA, K. - KISHIMOTO, S.: Protective effect of taurine against isoprenaline-induced myocardial damage. Basic Res. Cardiol., 81, 1986: 473-481

PAPIES, B. - SCHIMKE, I.-MORITZ, V.: Enhanced formation of lipid peroxides might contribute to high sensitivity of spontaneous hypertensive rats toward isoproterenol-induced myocardial damage. Biochim. Acta, 48, 1989: 681-687

SIMIAND, J. - KEANE, P. E. - MORRE, M.: The staircase test in mice- a simple and efficient procedure for primary screening of anxiolytic agents. Psychopharmacology. 34, 1984: 48-53

VENAULT P.,-CHAPOUTHIER G.,-DE CARVALHO L. P.,-SIMIAND J.,-MORRE M.,-DODD R. H.,-ROSSIER J.: Benzodiazepine impairs and teta-carboline enhances performance in learning and memory tasks. Nature, 321, 1986: 864-866

WARDLAW, A. C.: Practical statistics for experimental biologists. John Wiley and Sons Ltd., Chicester, New York, 1st ed., 1985, 290 pp. 